\title{
Ernesto Sábato y el Hombre Supérfluo
}

La crítica ha notado el obvio vínculo conceptual entre El tünel y la literatura rusa. En un estudio excelente, ${ }^{1}$ Tamara Holzapfel ha pun. tualizado las relaciones entre Sábato y Dostoevsky en su novela, Notes from the Underground, notando que Sábato mismo comenta una hermandad espiritual entre Rusia y Argentina en El escritor y sus fantasmas:

Los rusos tenían hacia mediados del siglo pasado problemas muy parecidos a los nuestros, y por causas sociales muy semejantes. Uno de los problemas fue el de la llamada "literatura nacional" y la lucha entre occidentalistas y eslavófilos... ¿Usted ha leído Oblomov? Pues si en lugar de tomar té ese caballeto toma mate puede pasar aceptablemente por cierto género de argentino de hace unas décadas. $\mathrm{La}$ desorganización, el sentido del tiempo precapitalista, la desmesura, la pampa y la estepa, la vida patriarcal de nuestras viejas familias, Ia educación europea y afrancesada, el desdén y al mismo tiempo el orgullo por lo nacional. .. etcétera, etcétera."

Creemos que es innegable la correspondencia entre la obra de Dos. toevsky y El thinel. Sin embargo, si Pablo Castel, el protagonista, es un prototipo del "underground man" creado por Dostoevsky, debemos dar. nos cuenta también de que el hombre subteráneo es una continuación de una tradición importante en la temática de la literatura rusa del siglo $\mathrm{XIX}$ - la del "hombre superfluo", el hombre abúlico que razona en vez de actuar, un tipo literario que aparece con insistencia en la literatura rusa de $\mathrm{l}_{\mathrm{a}}$ "edad de oro" del siglo xIx. Como comenta S. D. Mirsky

1 Tamara Holzapfel, "Dostoevsky's 'Notes from the Underground' and Sábatos 'El túnel'," Hispania, 51, No. 3 (September 1968), 440-46.

2 Ernesto Sábato, El escritor y sus fantasmas (Buenos Aires: Aguilar, 1963), pp. 31-32. 
en su meritoria historia de la literatura rusa: "The phrase 'a superfluous man' had an extraordinary fortune and is still applied by literary and social historians to the type of ineffective idealist portrayed so often by Turgenev and his contemporaries." 3

Es importante notar que Pablo Castel aparenta todos los rasgos psicológicos de este tipo literario y, por ende, continúa esta larga tradición. Este arquetipo ruso correspondía a una realidad social - la del rico estanciero que degeneraba en la soledad de un país de grandes extensiones; aunque de Pushkin a Dostoevsky, éste evolucionó de un romántico rico y culto, abrumado por un tedio metafísico, a un anti-héroe existencial. Es una figura que se manifiesta en algunas de las obras más importantes de la literatura rusa, entre ellas: Eugene Onegbin (1831) el poema narrativo del romántico Alexander Pushkin (1799-1837); la novela, también romántica, A Hero of Our Time (1840) de Mikhail Lermontov (1814-1841); dos novelas de Ivan Turgenev (1818-1883), Rudin (1856). y Diary of a Superfluous Man (1850), más un cuento, "Prince Hamlet of Shchigrovo", y Oblomov (1859) de Ivan Goncharov (1812-1891). Más tarde los protagonistas de las novelas de Dostoevsky -Raskolnikov, el joven intelectual de Crime and Punisbment (1866); Golyakdin, el humilde burócrata de The Double (1846), y el narrador de Notes from The Underground (1864) —, muestran muchas de las debilidades neuróticas del hombre superfluo.

El hombie subterráneo tiene importancia en la literatura como precursor de una sensibilidad moderna. Anuncia un pesimismo nuevo, que expone al hombre, no como dueño de su propia conducta en su capacidad intelectual, sino como víctima de poderosos y contradictorios impulsos irracionales. ${ }^{4}$ Paradójicamente, Pablo Castel razona mucho; sin embargo, él también es básicamente irracional porque, lejos de dominar su mundo por medio de su inteligencia, construye una barrera artificial entre sí mismo y el mundo, paralizándose en una abulia irracional. Esta irracionalidad se manifiesta en: a) un sentido de inferioridad que le lleva a protegerse con un falso complejo de superioridad; b) una manía de analizar todas sus ideas y acciones como una barrera negativa contra los azares de la vida. El mismo lo expresa muy bien cuando se interroga:

\footnotetext{
${ }^{3}$ D. S. Mirsky, A History of Russian Literature, ed. Francis J. Whitfield (New York: Alfred A. Knopf. 1966), p. 189.

"William Barret, Irrational Man (Garden City, New York: Doubleday \& Co., 1962), pp. 136-38; Barrett, What Is Existentialism? (New York: Grove Press, 1964), pp. 49, 109.
} 
¿Por qué esa manía de querer encontrar explicación a todos los actos de la vida?... En esos encuentros imaginarios había analizado diferentes posibilidades. Conozco mi naturaleza y sé que las situaciones imprevistas $y$ repentinas me hacen perder todo sentido, a fuerza de atolondramiento y de timidez. ${ }^{5}$

Es de gran interés hallar precisamente estos mismos matices psicológicos del hombre superfluo en el libro epónimo de $1_{a}$ tradición, Diary of a Superfluous Man de Turgenev. El protagonista, Chulkaturin, se refiere a sí mismo como un hombre inútil, superfluo, admitiendo que existe una barrera entre él y el mundo, como el "túnel" psicológico de la novela argentina:

Since I'm a superfluous man and locked up in myself, it's fright. ening for me to say what I think, especially because I know ahead of time that I'll express it terribly badly. . . between my thoughts and feelings and the expression of these thoughts and feelings there existed some meaningless, incomprehensible, and insurmountable barrier. And when I made up my mind to overcome this obstacle by force, to break down this barrier-my gestures, my facial expression, my whole being took on an aspect of agonizing strain... I would analyze myself down to the last thread, compare myself to others, recall the smallest glances, smiles, words of the people in front of whom I had been about to open up; I would see everything in the worst light... I was going around like a squirrel in a cage. ${ }^{\circ}$

Este miedo de hablar por temor a exponerse al ridículo de otros es precisamente el miedo que revela Castel. Reflexiona tanto sobre un propuesto encuentro con María, su novia, que cuando finalmente la encuentra, está paralizado por las múltiples variantes de conducta. Después se da cuenta de que existía una barrera mental entre sus ideas y sus acciones:

Mi cabeza es un laberinto oscuro. A veces hay como relámpagos que iluminan algunos corredores. Nunca termino de saber por qué hago ciertas cosas... Me sentía bastante tonto: de ninguna

- Ernesto Sábato, El tzinel (Buenos Aires: Editorial Sudamericana, 1970), pp. 12, 16. (todas las referencias que siguen son a esta edición).

6. Ivan Turgenev, Five Short Novels, trans. Franklin Reeve (New York: Bantam Bonks, 1961), pp. 9, 10. (las referencias que siguen son a esta edición). 
manera era esa mi forma de ser. Hice un gran esfuerzo mental: ¿acaso yo no razonaba? Por el contrario, mi cerebro estaba cons. tantemente razonando, como una máquina de calcular... (p. 41)

En la novela de Turgenev, Chulkaturin es un artista, un escritor que, como Pablo Castel, está preocupado constantemente por los celos y las dudas que tiene de su novia. Como admite este hombre superfluo ruso:

The misfortune of lonely and timid people-timid out of pridelies precisely in the fact that... Their own ideas and observations get in their way at every step... Besides, I had privately been making my unhappy brain work so hard, slowly turning over everything I observed or noticed in the course of the day before, that... I hardly had the strength to watch again. (pp. 19, 25)

Pablo Castel repite insistentemente palabras como: vertiginoso, La. berinto, vorágine, vértigo, tumultuosamente - palabras que profiere subconscientemente porque indican su confusión interior. Asimismo, Chulkaturin indica su debilidad animica con palabras similares:

Unsaid, unfinished thoughts like that kept coming back a thousand times and spun in my head like a monotonous whirlwind. I repeat, I went back to the Ozohogins' the same over-anxious, suspicious, tense man I had been since childhood. (p. 22)

En el cuento de Turgenev, "Prince Hamlet of Shchigrovo" de la colección A Sportsmian's Notebook, el narrador asiste a una tertulia en una estancia rica donde se encuentra con un hombre superfluo que se describe como un "Prince Hamlet of Shchigrovo". Este, que nunca revela su nombre verdadero, expone una personalidad y una historia personal notablemente similares a estos otros personajes - considera su vida inne. cesaria, superflua; se siente incapaz de acción, y sufre de una difidencia oculta:

You and I are both decent people, that's to say, egoists: you haven't the slightest concern with me, nor I with you;... I'm shy, you see, not shy in the sense of being an insignificant wretch of a provincial, but in the sense of being a man of intense selfesteem... So I'm a bird of the same feather as yourself; I'm no 
bumpkin from the steppes, as you suppose... I too am a prey to reflection, and there's nothing spontaneous about me at all.7

Finalmente admite que siente una desesperación que desemboca en un masoquismo nihilista:

In one of Voltaire's tragedies... there is a gentleman who rejoices in having reached the extreme limit of misfortune. Although there is nothing tragic about my fate, I must confess that I have expe. rienced something of the same sort. I have known the poisonous delights of cold despair; I have learnt how sweet it is to spend a whole morning lying motionless in bed and cursing the day and hour of my birth. (p. 301)

La superioridad que siente Pablo Castel nace de su desdén por el resto de la humanidad. Es una superioridad que refleja su inestabilidad psicológica en un complejo de inferioridad. Es el orgullo artificial que evidencian otros personajes - Raskolnikov de Crime and Punishment, el narrador de Notes from the Underground y, como vemos aquí, Prince Hamlet of Shchigrovo y Chulkaturin. Otra figura notable en esta lista debe ser, Pechorin, el protagonista de la bella novela romántica, $A$ Hero of Our Time de Mikhail Lermontov. Pechorin describe una vida de aventuras y percances por las estepas rusas en una novela emocionante y exótica. No obstante, esta obra contiene también una profundización del temperamento romántico que le da un valor permanente-Pechorin es el prototipo del romántico aburrido y cínico que busca lo inasequible en una vida que no entiende. En algunos pasajes significativos revela algunos pensamientos íntimos que prefiguran claramente el negativismo del hombre subterráneo, hablando también, de paso, de una superioridad restricta que resulta de su timidez:

1 Turgenev, A Sportsman's Notebook, trans. Charles and Natasha Hepburn (New York: The Viking Press, 1957), pp. 285, 86

8 Es notable que este sentido neurótico de la superioridad existe en un plano moral. Estos personajes, tanto Castel como Raskolnikov, exponen la supremacia nietzscheana según la cual un individuo está libre de las restricciones morales del resto de la humanidad. El crítico Marc Slonim señala a Pechorin de $A$ Hero of Our Time, como el verdadero precursor de esta actitud psicológica en la literatura rusa: "While several critics have stressed the analogy between Raskolnikor and Rastignac in Balzac's Père Goriot, less attention has been paid to the link between Dostoevsky's rebels and Lermontov's A Hero of Our' Own Times; Pechorin is undoubtedly one of the first 'supermen' in Russian literature." Marc Slonim, An Outline of Russian Literature (New York: Mentor Books, $1959)$, p. 101, 
Yes, such was my lot since my very childhood! Everybody read in my face the signs of bad inclinations which were not there, but they were supposed to be there-and so they came into exis. tence. I was modest-they accused me of being crafty: I became secretive. I felt deeply good and evil--nobody caressed me, every. body offended me: I became rancorous. I was gloomy-other children were merry and talkative. I felt myself superior to them - but was considered inferior: I became envious. I was ready to love the whole world.-none understood me: and I learned to hate. My colorless youth was spent in a struggle with myself and with the world. Fearing mockery, I buried my best feelings at the bottom of my heart: there they died... And then in my breast despair was born-not that despair which is cured with the pistol's muzzle, but cold, helpless despair, concealed under amiability and a good-natured smile. I became a moral cripple. One half of my. soul did not exist; it had withered away, it had evaporated, it had died.?

El hombre subterráneo de la famosa novela de Dostoevsky, Notes from The Underground, es la culminación de esta tradición. Con esta novela aparece un monstruo de despecho, envidia y dudas; un hombre completamente antipático, un ser anormal. Sin embargo, no es un caso patológico completamente anormal, sino una extensión extrema de muchas de las manifestaciones psicológicas del hombre moderno que llegarán a ser lugares comunes de la literatura del siglo xx. Como admite él mismo:

we are all divorced from life, we are all cripples, every one of us, more or less... As for what concerns me in particular I have only carried to an extreme in my life what you have not dared to carry halfway, and what's more, you have taken your cowardice for good sense, and have found comfort in deceiving yourselves. So that perhaps, after all, there is more life in me than in you. ${ }^{10}$

9 Mihail Lermontov, A Hero of Our Time, trans. Vladimir Nabokov in collaboration with Dmitri Nabokov (Garden City, New York: Doubleday \& Co., 1958), pp. 126-27.

${ }_{10}$ Fyodor Dostoevsky, Three Shont Novels of Dostoevsky, trans. Constance Garnett, revised and ed. Avrahm Yarmolinsky (Garden City, New York: Doubleday \& Co., 1961), pp. 296-97. (Todas las referencias que siguen son a esta edición). 
Literariamente el hombre subterráneo es una creación en extremo profunda. No es una sola personalidad sino un doble literario, una extensión de Golyakdin, el dependiente de The Double, quien también representa el anti-héroe humilde que reside en cada hombre. El hombre subterráneo es un hombre superfluo que patentiza en sus dualidades las emociones contradictorias que ya hemos notado en otras obras: es humilde y orgulloso, se cree superior al resto del mundo, pero está tan inseguro de sí mismo que es incapaz de acción. Como lo describe Ernest Simmons: "he thirsts for power and is powerless, he desires to torture and to be tortured to debase himself and to debase others, to be proud and to humble himself." 11

Tal vez lo que más aúna la personalidad de Pablo Castel con la del hombre subterráneo es la concepción que tienen ambos de su propia absurdidad. Ambos abrigan una individualidad extremada que les hace sentir su aislamiento del resto del mundo y que, a su vez, les hace temer neuróticamente el caer en el ridículo. Muy importante en El túnel es $\mathrm{l}_{2}$ repetición insistente de palabras y expresiones reveladoras como "era grotesco" (p. 27), "Esos conglomerados tienen una cantidad de atributos grotescos," (p. 18) "sentí que en esos momentos estaba haciendo algo desproporcionado y monstruoso," (p. 29) "me sentí grotesco," (p. 30) "era grotesco que un hombre conocido corriera por la calle detrás de una muchacha." (pp. 31-32) Pablo Castel expresa el asco que siente por el mundo $y$, subconscientemente, por sí mismo. $\Lambda$ veces se vale de metáforas o imágenes que son repugnantes; por ejemplo: "mi pensamiento era como un gusano ciego y torpe," (p. 29); "es. taría en un desierto negro, atormentado por infinitos gusanos hambrien. tos." (p. 147) El hombre subterráneo se refiere a sí mismo con los mismos términos: "I want now to tell you... why I could not even become an insect. I tell you solemnly that I have many times tried to become an insect. But I was not equal even to that." (p. 182) En otra ocasión admite: "I, for instance, have a great deal of amour-propre. I am as suspicious and prone to take offense as a humpback or a dwarf." (p. 185).

El anti-héroe de Dostoevsky es superfluo porque ha llegado al ex. tremo de la inacción por el exceso de su razón:

All "direct" persons and men of action are active just because they are stupid and limited... how am I, for example, to set my

11 Ernest J. Simmons, Dostoevsky (New York; Vintage Books, 1962), p. 122, citado en Holzapfel, p. 243. 
mind at rest? Where are the primary causes on which I am to build? Where are my foundations? Where am I to get them from? I excercise myself in reflection, and consequently with me every primary cause at once draws after itself another still more primary, and so on to infinity... Oh, gentlemen, do you know, perhaps I consider myself an intelligent man, only because all my life I have been able neither to begin nor to finish anything. (Pp. 193-94)

Pablo Castel ostenta un orgullo cínico y una timidez increíble: 12 dualidad emocional típica del hombre superfluo. Esta se revela en su menosprecio del resto de la humanidad: "En general, la humanidad me pareció siempre detestable" (p. 49), una actitud que se transparenta en su crítica de lo que él llama "la repetición del tipo" (p. 18); "esos conglomerados tienen una cantidad de atributos grotescos: la reptición del tipo, la jerga, la vanidad de creerse superiores al resto." (p. 18) Moralmente se considera por encima de la moral del resto de la huma. nidad, y declara, como Raskolnikov de Crime and Punisbment, que un individuo superior tiene el derecho a matar a un individuo desagradable. Cree que en una sociedad hipócrita "los criminales son gente más limpia, más inofensiva; esta afirmación... es una honesta y profunda convicción. ¿Un individuo es pernicioso? Pues se lo liquida y se acabó." (p. 10) Esta es también la falsa superioridad que exhibe el hombre subterráneo. Se cree mejor que sus compañeros pero, al mismo tiempo, se contradice casi inmediatamente:

Of course, I hated my fellow-clerks one and all, and I despised them all, yet at the same time I was, as it were, afraid of them. In fact, it happened at times that I thought more highly of them than of myself. It somehow happened quite suddenly that I alternated between despising them and thinking them superior to myself. (p. 216)

Es obvio que su inseguridad neurótica se basa, como admite Prince Hamlet of Shchigrovo, en una vanidad superficial:

It is clear to me now that, owing to my unbounded vanity and to the high standard I set myself, I often looked at myself with furious discontent, which verged on loathing, and so I inwardly attributed the same feeling to everyone. (p. 216) 
Después de la primera lectura de El zinnel la personalidad del artista Pablo Castel puede parecer un fenómeno raro en la literatura. Un estudio de sus antecedentes demuestra, sin embargo, que los temores, ansiedades y dudas de este anti-héroe "existencialista" 12 existen ya en una literatura cuyas raíces el mismo Ernesto Sábato reconoce como intimamente ligadas con el alma y la literatura argentinas.

University of Maryland.

Arthur A. Natella JR.

12 Este estudio sugiere, por tanto, que varias cualidades generalmente consideradas como "modernas" en realidad no son nuevas sino extensiones de tendencias literarias anteriores. Es nuestra tesis que el contenido "existencialista" del movimiento romántico todavia queda por explorar. 
